\title{
A cross-sectional survey of knowledge, attitude and practice associated with COVID-19 among undergraduate students in China
}

Yaling Peng ${ }^{1 \dagger}$, Chenchen Pei ${ }^{2 \dagger}$, Yan Zheng ${ }^{1 \dagger}$, Juan Wang ${ }^{1}$, Kui Zhang ${ }^{1}$, Zhaohui Zheng ${ }^{1}$ and Ping Zhu ${ }^{1 *}$

\begin{abstract}
Background: The COVID-19 pandemic has become a great threat to public health, which has greatly impacted the study and life of undergraduate students in China. This study aims to perform a survey of their knowledge, attitude and practice (KAP) associated with COVID-19.

Methods: A cross-sectional survey was designed to gather information regarding the COVID-19 related KAP among undergraduates during the home isolation in the outbreak. Subjects were recruited from 10 universities in Shaanxi Province, China. Enrollees voluntarily submitted their answers to a pre-designed questionnaire online.

Results: A total of 872 subjects (female, 534; male, 338) were enrolled with ages from 17 to 25 years old. This cohort included 430 medical and 442 non-medical students, 580 freshmen and 292 higher school year students. There were 453 from public schools and 442 from private school, residing in 28 regions and provinces at the time of study. Results showed that appropriate knowledge was acquired by $82.34 \%$ subjects; the levels were significantly higher in undergraduates from public universities and medical majors than those from private schools and nonmedical majors $(p<0.05)$. 73.81\% subjects reported positive attitudes; females showed significantly higher levels of positive attitudes than males $(p<0.05)$. Proactive practice was found in $87.94 \%$ subjects. Using a common scoring method, the overall scores for Knowledge, Attitude and Practice were $4.12 \pm 0.749$ (range: $0 \sim 5$ ), $8.54 \pm 1.201$ (range: $0 \sim 10$ ), and $8.91 \pm 1.431$ (range: $0 \sim 10$ ), respectively. There was a positive correlation between attitude and practice $(r=0.319, p<0.05)$ in the whole study group. Total KAP score was $21.57 \pm 2.291$ (range: $0 \sim 25)$, which was significantly different between gender groups and major groups.
\end{abstract}

Conclusions: Most undergraduates acquired necessary knowledge, positive attitude and proactive practice in response to COVID-19 outbreak; but their KAP scores significantly varied by gender, major and school types.

Keywords: COVID-19, Knowledge, attitude and practice, Undergraduates

\footnotetext{
* Correspondence: zhuping@fmmu.edu.cn

The first authorship is equally shared between Yaling Peng, Chenchen Pei and Yan Zheng.

'Department of Clinical Immunology, PLA Specialized Research Institute of

Rheumatology \& Immunology, Xijing Hospital, Fourth Military Medical

University, No. 127 Changle West Rd., Xi'an 710032, Shaanxi, China

Full list of author information is available at the end of the article
}

(c) The Author(s). 2020 Open Access This article is licensed under a Creative Commons Attribution 4.0 International License, which permits use, sharing, adaptation, distribution and reproduction in any medium or format, as long as you give appropriate credit to the original author(s) and the source, provide a link to the Creative Commons licence, and indicate if changes were made. The images or other third party material in this article are included in the article's Creative Commons licence, unless indicated otherwise in a credit line to the material. If material is not included in the article's Creative Commons licence and your intended use is not permitted by statutory regulation or exceeds the permitted use, you will need to obtain permission directly from the copyright holder. To view a copy of this licence, visit http://creativecommons.org/licenses/by/4.0/. The Creative Commons Public Domain Dedication waiver (http://creativecommons.org/publicdomain/zero/1.0/) applies to the data made available in this article, unless otherwise stated in a credit line to the data. 


\section{Background}

In late December 2019, a cluster of patients with an outbreak of pneumonia of unknown cause was reported in Wuhan, China [1]. By January 7, a novel coronavirus, severe acute respiratory syndrome coronavirus 2 (SARS$\mathrm{CoV}-2$ ), was identified as the cause to the coronavirus disease 2019 (COVID-19) [2]. Virus quickly spread in other regions in China as well as other countries; human-to-human transmission was proved [3]. World Health Organization (WHO) declared COVID-19 a Public Health Emergency of International Concern on January 30, 2020 [4]. As of July 21, there were totally 14,562,550 confirmed cases and 607,781deaths in the world [5].

To mitigate the outbreak, China quickly announced the highest-level public emergency response and took a series of extraordinary measures during the extended Spring Festival national holiday, including imposing a lockdown in Wuhan. At the same time, a series of other measurements were imposed in the entire country, including rigorous in-door quarantine, person-to-person health check-up, massive disinfection, ubiquitous public health education programs, as well as school and workplace closures [6]. Ubiquitous public health education programs, including internet messages, broadcasting and multimedia reports, virtual classes, e-hospital consultations and flyers of educational materials, played a vital role in public readiness. The outbreak put entire educational system in unprecedented difficult situations; particularly, undergraduate students represented a special group that was at the ages to acquire autonomy and independence of life but with limited experiences. Therefore, their perceptions and behaviors were posited to be greatly affected by the pandemic, which needed to be explored. In this study, we conducted a cross-sectional survey of knowledge, attitude and practice (KAP) associated with COVID-19 among undergraduates in China to evaluate the readiness of Chinese undergraduate students in response to this pandemic.

\section{Methods}

\section{Study subjects}

The enrollees of this survey were from 10 universities (including both public and private ones) in Shaanxi Province, China. Data were collected using an online convenient questionnaire tool, e.g., WJX (https://www. wjx.cn/). The survey was taken from February 23 to 28, 2020, a period when the general public was ordered to stay home isolation at the peak of the outbreak. To ensure the validity and accuracy of collected data, investigators made detailed instructions about the study objectives to all student counselors who distributed the questionnaire to subjects beforehand. The survey tool automatically verified that all questions had to be filled completely before submission and could not be submitted twice. All subjects were informed the survey purpose and signed written consents were obtained online before they started answering the questions (as detailed in Ethics Approval and Consent to Participate Section).

\section{Survey tool and scoring method}

The questionnaire [see Additional File 1] included 7 demographic variables (gender, age, hometown, name of university, type of school, grade, and major) and KAP variables encompassing 5 variables about Knowledge section of COVID-19 (classification of infectious disease, main transmitting route, main clinical manifestation, incubation period and susceptible population), 5 variables about Attitude section towards COVID-19 (human-tohuman transmission, wild animal consumption, endurance to emergency, impact on study, and pandemic control measures), and 5 variables of Practice section related to COVID-19 (response to symptoms, frontline rescue help, meeting with cured patients, post-close contact response, and return to school). The Knowledge section was developed with questions from COVID-19 Diagnosis and Treatment Protocol (Tentative Version Six) issued by National Health Commission of China [7]. The Attitude and Practice sections were developed by investigators on the basis of the scenarios most likely encountered by undergraduate students.

A common scoring method was used for this KAP questionnaire as follows: (1) 1 point for correct and 0 for incorrect answers in the Knowledge Section, (2) 2 for positive, 1 for neutral and 0 for negative options in the Attitude Section, and (3) 2 for proactive, 1 for neutral and 0 for passive options in the Practice Section. The score ranges were $0 \sim 5$ for Knowledge, $0 \sim 10$ for Attitude, $0 \sim 10$ for practice, and $0 \sim 25$ for total KAP.

\section{Data processing and analysis}

Data were analyzed using SPSS 18.0 software. T test was used to compare mean values of variables. Chi square test was utilized to compare categorical variables and ratios. Pearson or Spearman correlation analysis was used to compare correlations between two variables. $P<0.05$ was considered of statistical significance.

\section{Results}

\section{Demographic characteristics of subjects}

All subjects $(n=872)$ were recruited from 10 universities in Xi'an, Shaanxi Province, including five public and five private schools. Among them, 534 out of 872 (61.2\%) were females and 338 out of 872 (38.8\%) were males. There were $49.3 \%$ (430 out of 872 ) medical students and $50.7 \%$ (442 out of 872 ) non-medical majors. 51.9\% (453 out of 872 ) attended public schools and $50.7 \%$ (442 out of 872 ) were from private schools. $66.5 \%$ (580 out of 
872) were in their first year and the rest were in other higher grades. The average age of subjects was $20.1 \pm 0.1$ with a range between 17 and 25 years old. The hometown of student was reported to cover 28 provinces, autonomous regions and municipalities of China.

\section{Knowledge of COVID-19}

COVID-19 related knowledge was assessed by 5 categories. Each question and answer options were described with graded scores in Table 1. Among the total 4360 collected answers, 3590 (82.3\%) were correct. The female students had significantly a higher score for $\mathrm{K} 5$ than the males $(p<0.05$, Table 2$)$; public school students showed significantly higher scores for $\mathrm{K} 1$ and $\mathrm{K} 4$ than private school students $(p<0.05$, Table 2$)$. No other statistical significance was found between groups (Table 2).

\section{Attitude toward COVID-19}

Questions about COVID-19 attitude included 5 categories. Each question and answer options were described with graded scores in Table 3. Among all 4360 submitted answers, 3218 (73.81\%) showed a positive attitude. The females had significantly higher scores than the males for A1 $(p<0.05)$ and A3 $(p<0.05)$ (Table 4). Students from public schools scored significantly higher than those from private schools for A2 $(p<0.05)$, A3 $(p<0.05)$ and A5 $(p<0.05)$ (Table 4$)$.

\section{Practice related to COVID-19}

Practice related to COVID-19 was assessed by 5 singlechoice questions. Each question and answer option were described with graded scores in Table 5. Among the 4360 answers collected, 3834 (87.9\%) indicated a proactive practice. The females had significantly higher score for questions P2 P5, except P1 (Table 6). Students in higher grades had a significantly higher score for P5 than freshmen (Table 6).

\section{Comparison of COVID-19 related KAP scores between different groups}

In the whole study population, the overall score for Knowledge was $4.1 \pm 0.7$ (range: $0 \sim 5$ ), Attitude was $8.5 \pm 1.2$ (range: $0 \sim 10$ ), and Practice was $8.9 \pm 1.4$ (range: $0 \sim 10$ ). There was a positive correlation between Attitude and Practice scores $(r=0.319, p<0.05)$. Subgroup analysis indicated that Knowledge level was significantly higher in students from public schools and medical programs than those from private schools and non-medical majors $(p<0.05)$ (Table 7$)$. There was a significantly higher score of Attitude in females than males

Table 1 COVID-19 knowledge among undergraduate students

\begin{tabular}{|c|c|c|c|}
\hline Variable categories & Options & Determination/ score & N (\%) \\
\hline \multirow[t]{3}{*}{ K1: What type of infectious disease is COVID-19? } & - Bacterial. & Incorrect/ 0 & $17(2.0)$ \\
\hline & • Viral. & Correct/ 1 & $848(97.3)$ \\
\hline & • I don't know. & Incorrect/ 0 & $7(0.8)$ \\
\hline \multirow[t]{4}{*}{ K2: What is the main transmission route of COVID-19? } & - Respiratory droplets and close contact. & Correct/ 1 & $862(98.9)$ \\
\hline & - Water. & Incorrect/ 0 & $2(0.2)$ \\
\hline & • Food. & Incorrect/ 0 & $5(0.6)$ \\
\hline & - I don't know. & Incorrect/ 0 & $3(0.4)$ \\
\hline \multirow[t]{4}{*}{ K3: How long is COVID-19 incubation period? } & $\cdot 1 \sim 14$ days. & Correct/ 1 & $579(66.4)$ \\
\hline & $\cdot 3 \sim 7$ days. & Incorrect/ 0 & $21(2.4)$ \\
\hline & - More than 14 days. & Incorrect/ 0 & $265(30.4)$ \\
\hline & •I don't know. & Incorrect/ 0 & $7(0.8)$ \\
\hline \multirow[t]{5}{*}{ K4: Who are susceptible to COVID-19? } & - The old and young. & Incorrect/ 0 & $297(34.1)$ \\
\hline & - People are generally susceptible. & Correct/ 1 & $441(50.6)$ \\
\hline & - Young adults. & Incorrect/ 0 & $11(1.3)$ \\
\hline & - People with pre-existing diseases. & Incorrect/ 0 & $117(13.4)$ \\
\hline & • I don't know. & Incorrect/ 0 & $6(0.7)$ \\
\hline \multirow[t]{6}{*}{ K5: What are the main clinical manifestations of COVID-19? } & - Fever and dry cough. & Correct/ 1 & $860(98.6)$ \\
\hline & - Fatigue. & Incorrect/ 0 & $3(0.3)$ \\
\hline & - Stuffy and runny nose. & Incorrect/ 0 & $1(0.1)$ \\
\hline & - Sore throat and myalgia. & Incorrect/ 0 & $2(0.2)$ \\
\hline & • Diarrhea. & Incorrect/ 0 & $0(0.0)$ \\
\hline & • I don't know. & Incorrect/ 0 & $6(0.7)$ \\
\hline
\end{tabular}



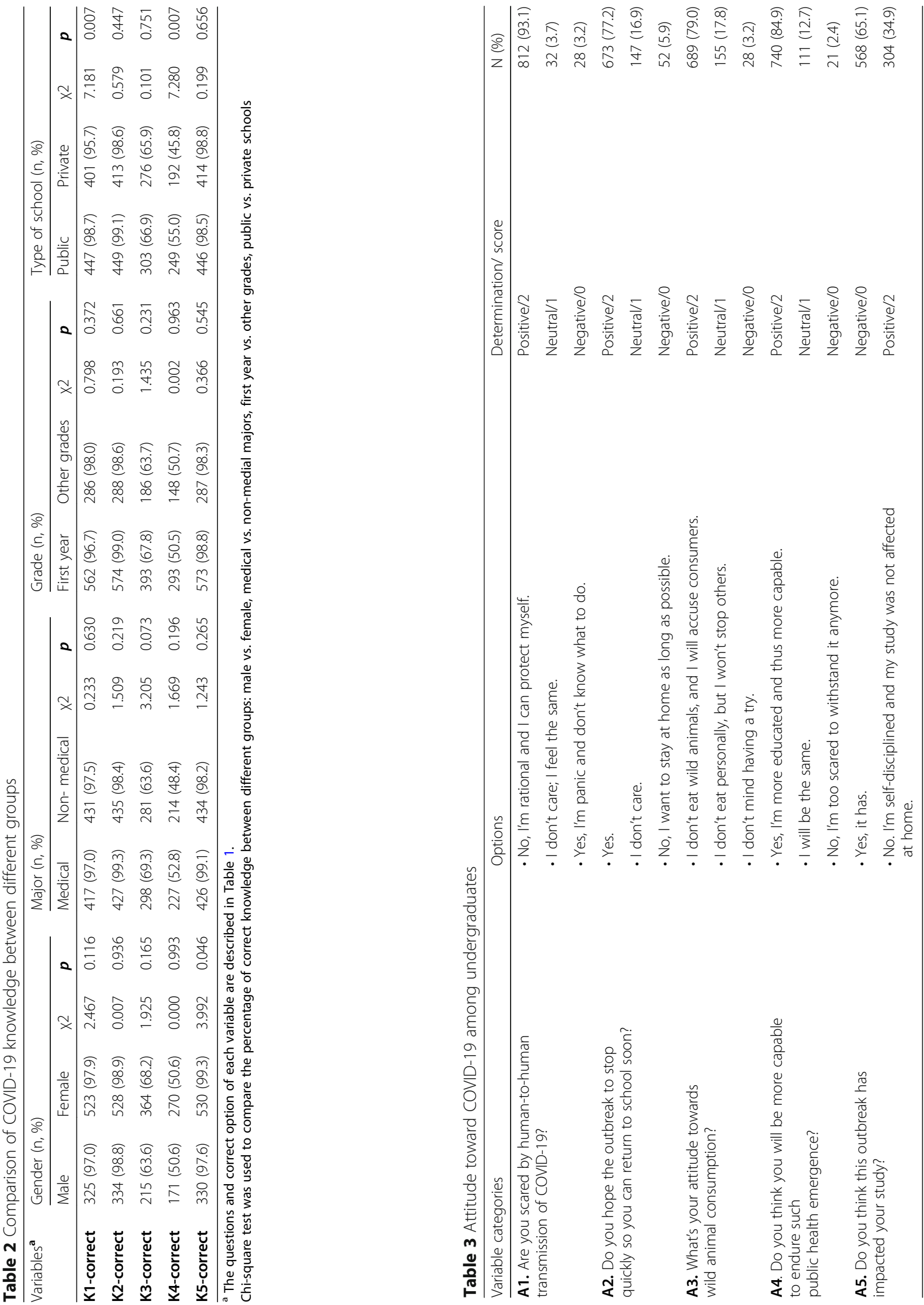

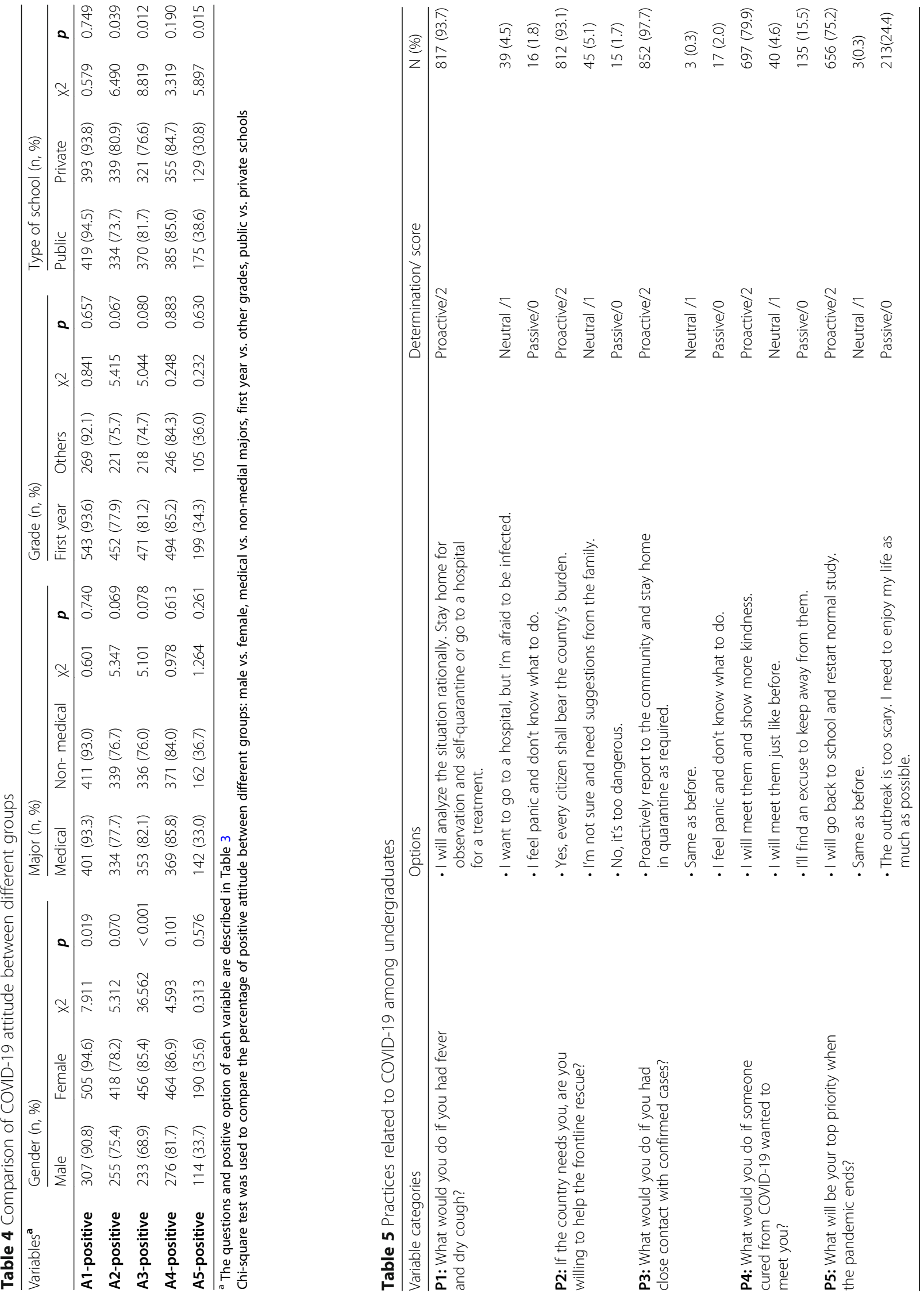

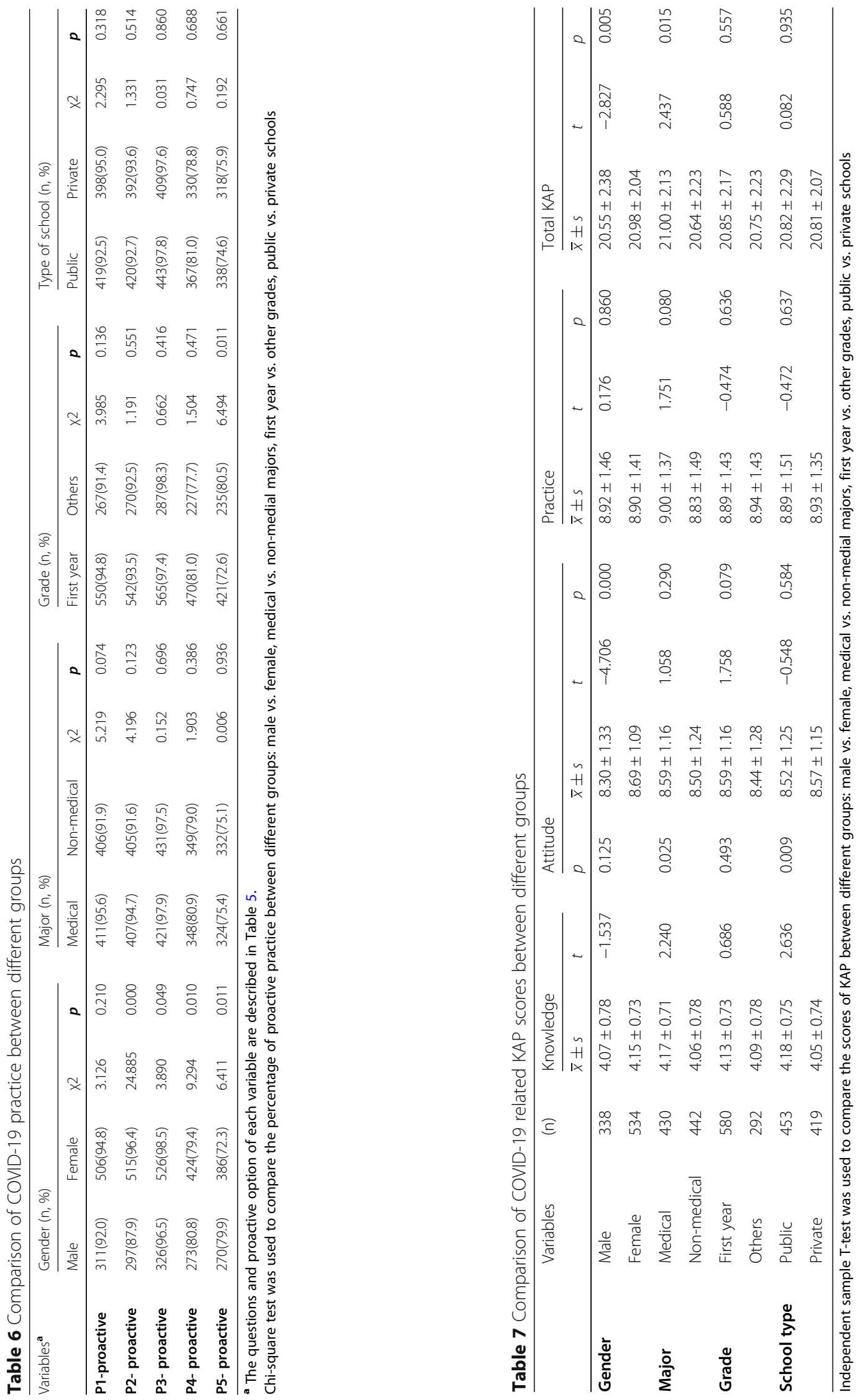
$(p<0.05)$ (Table 7). Practice level was found no statistically significant difference between groups by gender, grade, major or school style (Table 7).

Total KAP score was $21.6 \pm 2.3$ among the subjects, in which a positive correlation was observed between the Attitude and Practice $(\mathrm{r}=0.319, p<0.05)$. Total KAP score was significantly different among gender groups and major groups $(p<0.05, p<0.05)$ (Table 7).

\section{Discussion}

Since the outbreak in epicenter Wuhan in December 2019, COVID-19 has rapidly become a threat to global public health and led to substantial socioeconomic damages in the whole world. Vigorous measurements have been enforcedly implemented including lockdown of Wuhan and community quarantine by Chinese central and local governments since the outbreak to mitigate the disease effectively. In addition, public health education has been recognized as an effective measure to prevent and control public health emergency for the public preparedness against such situation. It will lead the public to acquire appropriate knowledge, mitigate panic and seek for positive attitude, and comply with aligned and desired practices. All these KAP elements have been considered crucial to ensure effective prevention and control of the pandemic.

This cross-sectional survey on 872 undergraduate students found that most of them were well informed with COVID-19 related knowledge, showed positive attitude and proactive practice during the outbreak, indicating that effective health education was delivered by the massive public education campaigns (especially via Internet). This result is consistent with many other reports on H1N1 related KAP among university students in South Korea, UK and Hong Kong [8-10]. Our study also revealed that females had significantly higher score on the knowledge of "main clinical manifestation of COVID-19", in line with the result of an investigation on MERS in Saudi Arabian [11]. It has been shown that women is superior to men in terms of the knowledge and practice (hand hygiene, wearing a mask) related to infectious diseases (eg: H1N1, SARS, and MERS, etc) [10-15]. This gender difference also has been shown in our study that are evidenced by a better score on attitude score and KAP total score for females than males, including proper and rational protective measurements to reduce the risk of human-to-human transmission and aversion to wild animal consumption.

Students from public schools and medical programs showed a higher score for COVID-19 related knowledge. This could be explained by the characteristic educational situations in China. Since the past two decades, private universities have been begun to be established as a role player supplementary to the public educational system as per governmental policies. Comparing to private schools, public universities have been innately superior in their numbers and scales, quantity and quality of students and teachers, as well as supports from the authorities, etc [16]. Medical students showed a good score of knowledge which could be explained by their trainings in clinical medicine and public health. Their obligations and responsibilities to fight against this pandemic as future medical professionals are thought to drive them to present more positive attitudes and proactive practices during this public health emergency [17].

This investigation has some limitations. First, the convenient sampling method could not avoid the bias of subjective selection, thus diminishing the internal validity. Second, the nature of cross-sectional study design was unable to determine causality between the variables. Third, our subjects were enrolled from ten universities in a single city, though they were staying at home for isolation in twentyeight provinces and regions across the country at the time of survey. This might not reflect the actual situation of undergraduate students in Chinese universities as a whole.

To our knowledge, this study is the first investigation on the current KAP related to COVID-19 among Chinese undergraduate students. Therefore, it provides valuable insights into public health education and preventative measures in Chinese universities during the COVID-19 pandemic. Our results indicate that the majority of Chinese undergraduate students have acquired the basic knowledge of COVID-19, but their performance may vary by school types and majors. Attitude towards COVID-19 shows a gender disparity. Taken together, these results suggest that gender, major and school styles potentially affect student's responses to COVID-19 outbreak and acquisition of public health education, which should be drawn awareness to education and health authorities. These factors should also be accounted to formulate contingency plans or trainings for the students against similar public health emergencies in future.

\section{Conclusion}

Most Chinese undergraduate students understood the basic information, possessed positive attitude and presented proactive practice towards the outbreak of COVID-19, indicating the efficacy and success of present public health campaigns. However, results also revealed that gender, major and school types should be taken into consideration when health and education authorities 
tailor public health trainings and improve their preventative measures against this epidemic.

\section{Supplementary information}

Supplementary information accompanies this paper at https://doi.org/10. 1186/s12889-020-09392-z.

Additional file 1. English translation of the questionnaire.

\section{Abbreviations}

KAP: Knowledge, attitude and practice; COVID-19: Coronavirus disease 2019 SARS-CoV-2: Severe acute respiratory syndrome coronavirus 2; WHO: World Health Organization; SARS: Severe acute respiratory syndrome; MERS: Middle east respiratory syndrome

\section{Acknowledgements}

Authors thank Dr. Wenbin Tan from Department of Cell Biology and Anatomy, University of South Carolina School of Medicine, Columbia, SC, USA for his critical review of the manuscript.

\section{Authors' contributions}

YP conceptualized the study, designed survey and interpreted data; CP drafted the manuscript; $Y Z$ performed literature review and data analysis; JW performed the survey; $K Z$ critically reviewed and improved the manuscript; $\mathrm{ZZ}$ and PZ improved data interpretation and revised the manuscript. Al authors substantially contributed to the study and approved its submission.

\section{Funding}

This study receives no funding or financial support.

\section{Availability of data and materials}

The datasets used and/or analyzed during the current study are available from the corresponding author on reasonable request.

\section{Ethics approval and consent to participate}

This study was approved by the Ethics Committee of Xijing Hospital, and it conformed to the ethics guidelines of the Declaration of Helsinki. All the written consents were signed voluntarily and obtained online by all adult subjects or if subjects were under 18 , by a legal guardian for inclusion before subjects started answering the questions.

\section{Consent for publication}

Not applicable.

\section{Competing interests}

The authors declare that they have no competing interests.

\section{Author details}

${ }^{1}$ Department of Clinical Immunology, PLA Specialized Research Institute of Rheumatology \& Immunology, Xijing Hospital, Fourth Military Medical University, No. 127 Changle West Rd., Xi'an 710032, Shaanxi, China. ${ }^{2}$ Department of Dermatology, Xijing Hospital, Fourth Military Medical University, Xi'an, China.

Received: 3 April 2020 Accepted: 17 August 2020

Published online: 26 August 2020

\section{References}

1. Zhu N, Zhang DY, Wang WL, Li XW, Yang B, Song JD, et al. A novel coronavirus from patients with pneumonia in China. N Engl J Med. 2020; 382(8):727-33.

2. World Health Organization. Coronavirus disease 2019 (COVID-19) Papua New Guinea Situation Report 6. https://www.who.int/docs/default-source/ wpro\%2D\%2D-documents/countries/papua-new-guinea/covid-19/pngcovid-19-health-situation-report-06.pdf?sfvrsn=97936632 2 Accessed 9 Jul 2020.

3. Wang C, Horby PW, Hayden FG, Gao GF. A novel coronavirus outbreak of global health concern. Lancet. 2020;395(10223):470-3.
4. World Health Organization. Timeline of WHO's response to COVID-19. https://www.who.int/news-room/detail/29-06-2020-covidtimeline. Accessed 9 Jul 2020.

5. World Health Organization. Coronavirus disease 2019 (COVID-19) Situation Report - 183. https://www.who.int/docs/default-source/wha-70-and-phe/2 0200721-covid-19-sitrep-183.pdf?sfvrsn=b3869b3_2. Accessed 22 Jul 2020.

6. National Health Commission of China. Minutes of January 26 Press Conference (国家卫生健康委员会《2020年1月26日新闻发布会文字实录》) http://www.nhc.gov.cn/xcs/fkdt/202001/12ec9062d5d041f38e210e8b69b6 d7ef.shtml. Accessed 16 Mar 2020.

7. National Health Commission of China. COVID-19 Diagnosis and Treatment Protocol (Tentative Version 6) (国家卫生健康委员会《关于印发新型冠状 病毒肺炎诊疗方案 (试行第六版)》) http://www.gov.cn/zhengce/ zhengceku/2020-02/19/content_5480948.htm. Accessed 20 Feb 2020.

8. Lau JT, Griffiths S, Choi KC, Tsui HY. Widespread public misconception in the early phase of the H1N1 influenza pandemic. J Inf Secur. 2009;59(2):122-7.

9. Rubin GJ, Amlôt R, Page L, Wessely S. Public perceptions, anxiety, and behavior change in relation to the swine flu outbreak: cross sectional telephone survey. BMJ. 2009;2(339):b2651.

10. Park J-H, Cheong H-K, Son D-Y, Kim S-U, Ha C-M. Perceptions and behaviors related to hand hygiene for the prevention of $\mathrm{H} 1 \mathrm{~N} 1$ influenza transmission among Korean university students during the peak pandemic period. BMC Infect Dis. 2010;10:222

11. Al-Hazmi A, Gosadi I, Somily A, Alsubaie S, Saeed AB. Knowledge, attitude and practice of secondary schools and university students toward Middle East respiratory syndrome epidemic in Saudi Arabia: a cross-sectional study. Saudi J Biol Sci. 2018;25(3):572-7.

12. Lau JTF, Yang $X$, Tsui $H$, Kim JH. Monitoring community responses to the SARS pandemic in Hong Kong: from day 10 to day 62. J Epidemiol Community Health. 2003;57(11):864-70.

13. Tang CSK, Wong CY. Factors influencing the wearing of facemasks to prevent the severe acute respiratory syndrome among Chinese in Hong Kong. Prev Med. 2004:39(6):1187-93.

14. Leung GM, Ho LM, Chan SK, Ho SY, Bacon-Shone J, Choy RY, et al. Longitudinal assessment of community psychobehavioral responses during and after the 2003 outbreak of severe acute respiratory syndrome in Hong Kong. Clin Infect Dis. 2005:40(12):1713-20.

15. Rubin GJ, Amlôt R, Page L, Wessely S. Public perceptions, anxiety, and behaviour change in relation to the swine flu outbreak: cross sectional telephone survey. BMJ. 2009;339:b2651. https://doi.org/10.1136/bmj.b2651.

16. Mao JQ. A study on the main subjects of current higher education in China: current situation, causes and policy suggestion-from the comparative view of the public and private universities. Heilongjiang Higher Education Research. 2007;147(7):1-5 (毛建青，当前我国高等教育市场主体的现 状、原因及政策建议:民办高校与公办高校对比的视角。黑龙江高教研 究, 2007, 147(7):1-5.

17. Heung YY, Wong KY, Kwong WY, To SS, Wong HC. Daniel Wong. Severe acute respiratory syndrome outbreak promotes a strong sense of professional identity among nursing students. Nurse Educ Today. 2005;25(2): $112-8$.

\section{Publisher's Note}

Springer Nature remains neutral with regard to jurisdictional claims in published maps and institutional affiliations.

\section{Ready to submit your research? Choose BMC and benefit from:}

- fast, convenient online submission

- thorough peer review by experienced researchers in your field

- rapid publication on acceptance

- support for research data, including large and complex data types

- gold Open Access which fosters wider collaboration and increased citations

- maximum visibility for your research: over $100 \mathrm{M}$ website views per year

At BMC, research is always in progress.

Learn more biomedcentral.com/submissions 